\title{
PARTISIPASI MASYARAKAT DALAM PEMBENTUKAN PERUNDANG-UNDANGAN UNTUK MEWUJUDKAN INDONESIA SEJAHTERA DALAM PANDANGAN TEORI NEGARA KESEJAHTERAAN ${ }^{*}$
}

\author{
Darmini Roza ${ }^{1}$, Gokma Toni Parlindungan $\mathrm{S}^{2}$ \\ Universitas Ekasakti $^{1}$ \\ e-mail: darminirosa@gmail.com \\ Sekolah Tinggi Ilmu Hukum Padang ${ }^{2}$ \\ *e-mail: gokmatoniparlindungan@ gmail.com
}

\begin{abstract}
In the country of law, the law is one form of legal norms formulation in the life of the state. The existence of laws in a country has a strategic and important position, regardless of the conception of the law, hierarchy of legal norms, as well as from the function of law in general. People's welfare is one of the goals of the state. In the realization of the necessary mechanisms are reflected in the public policy that is made. This study aims to examine and examine the public participation in the formation of legislation to create the welfare state of Indonesia. The research of this scientific work, the type of normative legal research. The understanding of the welfare state can be applied in the formulation of legislation. Welfare is the dream of every society, and laws and regulations function as regulators and means of achievement. To realize the formation of responsive legislation in Indonesia, the formation of legislation in Indonesia must be subject to Article 5 and Article 6 of Law Number 12 Year 2011 on the Establishment of Legislation, And this is related to the formation of Legislation and adheres to the principles of the establishment of good legislation. So the welfare state can be realized.
\end{abstract}

Key Words: Participation; Society; Law; Welfare State; Indonesia.

\begin{abstract}
Abstrak
Di negara hukum, hukum merupakan salah satu bentuk perumusan norma hukum dalam kehidupan negara. Keberadaan hukum di suatu negara memiliki posisi strategis dan penting, terlepas dari konsepsi hukum, hierarki norma hukum, serta dari fungsi hukum secara umum. Kesejahteraan rakyat adalah salah satu tujuan negara. Dalam realisasi mekanisme yang diperlukan tercermin dalam kebijakan publik yang dibuat. Penelitian ini bertujuan untuk menguji dan menguji partisipasi publik dalam pembentukan undang-undang untuk menciptakan negara kesejahteraan Indonesia. Penelitian karya ilmiah ini, jenis penelitian hukum normatif. Pemahaman tentang negara kesejahteraan dapat diterapkan dalam perumusan undang-undang. Kesejahteraan adalah impian setiap masyarakat, dan hukum dan peraturan berfungsi sebagai pengatur dan sarana pencapaian. Untuk mewujudkan pembentukan legislasi responsif di Indonesia, pembentukan legislasi di Indonesia harus tunduk pada Pasal 5 dan Pasal 6 Undang-Undang Nomor 12 Tahun 2011 tentang Pembentukan Legislasi, Dan ini terkait dengan pembentukan Legislasi dan menganut prinsipprinsip pembentukan undang-undang yang baik. Sehingga negara kesejahteraan bisa terwujud.
\end{abstract}

Kata Kunci: Partisipasi; Masyarakat; Hukum; Negara Kesejahteraan; Indonesia.

\footnotetext{
* Naskah diterima: 28 Juli 2019, direvisi: 14 Agustus 2019, disetujui untuk terbit: 30 September 2019 Doi: $10.3376 /$ jch.v5i1.185
} 


\section{PENDAHULUAN}

Pembentukan undang-undang adalah bagian dari aktivitas dalam mengatur masyarakat yang terdiri atas gabungan individu-individu manusia dengan segala dimensinya, sehingga merancang dan membentuk undang-undang yang dapat diterima masyarakat kuas merupakan pekerjaan yang sulit (Zaka Firma Aditya, Muhammad Reza Winata: 2018). Kesulitan ini terletak pada kenyataan bahwa kegiatan pembentukan undangundang adalah suatu bentuk komunikasi antara lembaga yang menetapkan yaitu pemegang kekuasaan legislatif dengan rakyat dalam suatu negara (Pierre Andre Cote: 1991). Proses pembentukan undang-undang ini, di dalamnya terdapat transformasi visi, misi dan nilai yang diinginkan oleh lembaga pembentuk undang-undang dengan masyarakat dalam suatu bentuk aturan hukum. Pembentuk undang-undang sejak awal proses perancangan, telah dituntut agar undangundang yang dihasilkan mampu memenuhi berbagai kebutuhan. Pertama, mampu dilaksanakan; kedua, dapat ditegakkan; ketiga, sesuai dengan prinsipprinsip jaminan hukum dan persamaan hak-hak sasaran yang diatur; dan keempat, mampu menyerap aspirasi masyarakat (Retno Saraswati: 2009). Selain berbagai kesulitan tersebut, pembentuk undang-undang berpacu dengan dinamika perkembangan masyarakat yang terus berubah sejalan dengan nilai-nilai yang dianggap baik oleh masyarkat. Jadi, pembentukan undang-undang sebagai bagian dari proses pembentukan sistem hukum yang lebih luas tidaklah statis, tetapi mengalami dinamika perubahan.

Undang-Undang Dasar Negara Republik Indonesia Tahun 1945 (UUD 1945), sebagai hukum dasar, merupakan kesepakatan umum (konsensus) warga negara mengenai norma dasar (grundnorm) dan aturan dasar (grundgesetze) dalam kehidupan bernegara. Kesepakatan ini utamanya menyangkut tujuan dan cita-cita bersama, the rule of law sebagai landasan penyelenggara negara, serta bentuk institusi dan prosedur ketatanegaraan. Berdasarkan UUD 1945 ini, Indonesia ialah negara yang berdasarkan atas hukum (rechtstaat), tidak berdasarkan atas kekuasaan belaka (machtsrtaat). Negara juga menganut sistem konstitusional, dengan Pemerintahan berdasarkan konstitusi (hukum dasar), dan tidak bersifat absolut (kekuasaan yang tidak terbatas). UUD 1945 menjadi pedoman bagi pelaksanaan "demokrasi konstitusional" (constitusional democracy), yakni praktisi demokrasi yang tujuan ideologis dan teologisnya adalah pembentukan dan pemenuhan konstitusi (Saiful: 2014). Hal inilah yang membuat UUD 1945 sebagai konstitusi negara sebagai landasan konstitusional bangsa Indonesia yang menjadi dasar bagi setiap peraturan perundang-undangan di bawahnya. Oleh karena itu, dalam negara yang menganut paham konstitusional tidak ada satu pun perilaku penyelenggara negara dan masyarakat yang tidak berlandasakan konstitusi. 
Darmini Roza dan Gokma Toni P.S: Partisipasi Masyarakat Dalam Pembentukan...

Penghargaan yang tinggi terhadap peraturan perundang-undangan menjadi salah satu ciri yang dianut oleh sistem hukum kontinental. Sistem hukum kontinental mengutamakan hukum tertulis yang berupa peraturan perundangundangan yang merupakan produk legislasi sebagai sendi utama sistem hukumnya. Karena itu negara-negara yang berada dalam sistem hukum kontinental selalu berusaha menyusun hukum-hukumnya dalam bentuk tertulis dalam suatu sistematika yang diupayakan selengkap mungkin dalam sebuah kitab undang-undang (kodifikasi), sehingga sering pula disebut dengan sistem kodifikasi (codified law). Bahkan dalam perkembangannya di negara-negara yang menganut sistem hukum anglo saxon (common law) juga mulai mengakui keunggulan perundang-undangan dalam kehidupan bernegara sekarang ini.

Keberadaan undang-undang dalam suatu negara mempunyai kedudukan yang strategis dan penting, baik dilihat dari konsepsi negara hukum, hirarki norma hukum, maupun dilihat dari fungsi undang-undang pada umumnya. Dalam konsepsi negara hukum, undang-undang merupakan salah satu bentuk formulasi norma hukum dalam kehidupan bernegara. Dalam pandangan Paul Scholten, bahwa hukum itu di dalam perundang-undangan, sehingga orang harus memberikan tempat yang tinggi kepadanya (Reinstein, Rovert J: 2009). Keberadaan peraturan perundangundangan dan kegaiatan pembentukan undang-undang (legislasi) mempunyai peranan yang sangat penting dan strategis sebagai pendukung utama dalam penyelenggaraan pemerintahan. Hal ini didasarkan atas beberapa alasan, yaitu: 1) Peraturan perundang-undangan merupakan kaidah hukum yang mudah dikenali (diidentifikasi), mudah ditemukan kembali, dan mudah ditelusuri. Sebagai kaidah hukum tertulis, bentuk, jenis, dan tempatnya jelas, begitu pula pembuatnya; 2) Peraturan perundangundangan memberikan kepastian hukum yang lebih nyata karena kaidah-kaidahnya mudah diidentifikasi dan mudah ditemukan kembali; 3) Struktur dan sistematika peraturan perundangundangan lebih jelas sehingga memungkinkan untuk diperiksa kembali dan diuji baik segi-segi formal maupun materi muatannya; 4) Pembentukan dan pengembangan peraturan perundangundangan dapat direncanakan. Faktor ini sangat penting bagi negara-negara yang sedang membangun, termasuk membangun sistem hukum baru yang sesuai dengan kebutuhan dan perkembangan masyarakat (Liddle, R. William: 1999).

Cara memandang hukum secara formal sebagai tatanan norma hukum yang paling konsekuen adalah Hans Kelsen dalam Reine Recthslehre (The Pure Theory Of Law) karena memuaskan sebagai sebuah cara berpikir logis yang kemudian dikembangkan oleh Hans Nawiasky. Hans Nawiasky dalam Theorie von Stufenordnung der Recthsnormen mengemukakan bahwa undang-undang (Formell Gesetz) berada di posisi tengah- 
tengah yang menjembatani antara konstitusi atau aturan dasar/aturan pokok (Staatsgrundgesetz) dengan aturan pelaksana dan aturan otonom (Verordnung dan Autonome Satzung). Karena materi muatan konstruksi sebagai aturan dasar atau pokok pada prinsipnya sangat terbatas pada hal-hal yang pokok dan mendasar, maka untuk bisa dilaksanakan secara aktual perlu dirumuskan lebih lanjut dalam aturanaturan umum yang jelas dan terperinci dalam bentuk undang-undang dan selanjutnya baru dijabarkan lebih teknis dan terinci lagi dalam Aturan Pelaksana. Karena itu keberadaan undang-undang sangatlah penting karena merupakan penjabaran lebih lanjut dari konstitusi (Rahayu Prasetyaningsih: 2017). Hal demikian dapat dilihat dari tata urutan perundang-undangan di Indonesia menurut Pasal 7 Undang-Undang Nomor 12 Tahun 2011 tentang Pembentukan Perundang-Undangan, yang menyatakan jenis dan susunan hierarki perundangundangan (UUP3) adalah: a) UUD 1945; b) Ketetapan Majelis Permusyawaratan Rakyat; c) Undang-Undang/Peraturan Pemerintah Pengganti Undang-Undang; d) Peraturan Pemerintah; e) Peraturan Presiden; f) Peraturan Daerah Provinsi dan g) Peraturan Daerah Kabupaten/Kota.

Kesejahteraan rakyat merupakan salah satu tujuan bernegara. Dalam mewujudkannya diperlukan mekanisme tertentu yang tercermin dalam kebijakan publik yang dibuat. Permasalahan kebijakan atau sering disebut sebagai implementation gap adalah suatu keadaan dalam proses kebijakan selalu terbuka akan kemungkinan perbedaan antara apa yang direncanakan oleh pembuat kebijakan dengan apa yang senyatanya dicapai sebagai hasil atau prestasi dari pelaksanaan kebijakan. Hal ini salah satunya dikarenakan dalam proses implementasi kebijakan seringkali dikumpul oleh banyak kepentingan dan harapan terutama pengaruh persepsi setting lingkungan dimana kebijakan itu dilaksanakan (Agus Suryono: 2014). UUD 1945 mengamanahkan negara untuk memenuhi kemakmuran rakyat dan menyelenggarakan kesejahteraan sosial dalam satu bagian khusus, yaitu Bab XIV mengenai Perekonomian Nasional dan Kesejahteraan Sosial. Namun, wacana mengenai seberapa besar negara memainkan peranannya dalam konteks ini senantiasa berada dalam ruang perdebatan panjang. Sebagian berpendapat bahwa keterlibatan negara dalam pelaksanaan kedua hal tersebut adalah bersifat langsung (interventionist), sementara sebagian yang lain berpandangan bahwa negara memang memegang peranan dominan tanpa perlu mengambil alih keseluruhan peran tersebut (Bisariyadi: 2016).

Globalisasi memicu kecenderungan untuk menyerahkan segala urusan ke pemerintahan pada mekanisme "pasar" (market) dalam rangka meningkatkan efisiensi dan efektivitas. Pelayanan publik seperti di bidang kesehatan, transportasi dan jaminan sosial, yang sedianya diberikan langsung oleh negara, kini diserahkan pada pihak ketiga, yaitu sektor 
Darmini Roza dan Gokma Toni P.S: Partisipasi Masyarakat Dalam Pembentukan...

privat. Peran negara adalah dalam hal membuat peraturan dan mengawasi penerapan aturan-aturan yang harus ditaati oleh pihak- pihak yang terlibat. Beberapa ilmuwan politik menyatakan bahwa Indonesia mengarah pada model negara regulasi (Stewart Fenwick: 2009).

Salah satu indikasinya, negara memproduksi peraturan secara masif, terutama dalam lingkup peraturan perundang-undangan. Sisi negatif dari produksi peraturan perundang-undangan yang berlebihan adalah buruknya kualitas materi muatan yang terkandung serta banyaknya norma yang tumpang tindih antara satu dengan yang lain. Selaras dengan itu, the Organisation for Economic Co-operation And Development (OECD) dalam laporannya telah menangkap komitmen pemerintah Indonesia untuk menghasilkan produk perundang-undangan yang berkualitas sebagai upaya Indonesia dalam rangka meningkatkan kesejahteraan rakyat dan mempertahankan stabilitas politik dalam negeri.

\section{METODE PENELITIAN}

Metode pendekatan masalah yang digunakan berdasarkan permasalahan yang dirumuskan adalah penelitian yuridis normatif berupa pendekatan masalah melalui kajian pustaka dan peraturan perundang-undangan yang berlaku serta bahan-bahan dan literatur-literatur yang berhubungan dan menggambarkan keadaan yang sebagaimana mestinya berdasarkan perumusan masalah diatas. Ada beberapa metode pendekatan masalah yang akan dituangkan di dalam penulisan ilmiah ini, beberapa diantaranya adalah sebagai berikut: a) Pendekatan Perundang-undangan (Statute Approach). b) Pendekatan Sejarah (Historical Approach); dan c) Pendekatan Konseptual (Conceptual Approach), yang berkaitan dalam artikel ini (Laurensius Arliman S: 2018).

\section{HASIL DAN PEMBAHASAN}

\section{Mengenal Istilah Teori Negara Kesejahteraan}

Istilah negara kesejahteraan mengacu pada peran yang dimainkan negara dalam menyediakan berbagai layanan dan manfaat bagi para warga negaranya dalam pemeliharaan pendapatan dan kesehatan bahkan juga perumahan, pendidikan dan kegiatan sosial (Laurensius Arliman S: 2016). Sejak akhir abad ke-19, beberapa negara industri paling maju melibatkan diri dalam derajat, bentuk dan dampak yang berbeda dalam prinsip negara kesejahteraan. Pada tahun1884 Jerman menerapkan sistem asuransi nasional wajib pertama untuk penggulangan penyakit. Segera setelah itu Denmark, Selandia Baru dan Australia menerapkan pemberian pensiun kepada orang lanjut usia tanpa pungutan iuran. Namun, perkembangan yang paling signifikan terjadi pada tahun 1930-an dan 1940-an dengan, misalnya program New Deal di Amerika Serikat, perumahan rakyat (people's home) di Swedia, dan reformasireformasi kesejahteraan paska perang di Inggris, Perancis, dan Jerman (Laurensius Arliman S: 2016). Kebanyakan reformasi ini ditujukan untuk menyediakan kesempatan kerja bagi para pria yang 
didukung dengan tunjangan keluarga dan manfaat asuransi kesehatan, pengangguran, dan usia lanjut. Perkembangan sejarah dari sesuatu yang kadangkala disebut negara kesejahteraan Keynesian ini menjadi dasar dari makna istilah negara kesejahteraan (Eddy Kiswanto: 2005).

Teori Negara Kesejahteraan (welfare state) pernah diperkenalkan oleh Spicker, yang mendefinisikan negara kesejahteraan sebagai sebuah sistem kesejahteraan sosial yang memberi peran lebih besar kepada negara (pemerintah) untuk mengalokasikan sebagian dana publik demi menjamin terpenuhinya kebutuhan dasar warganya. Negara kesejahteraan ditujukan untuk menyediakan pelayananpelayanan sosial bagi seluruh penduduknya, sebaik dan sedapat mungkin. Negara kesejahteraan berupaya untuk mengintegrasikan sistem sumber dan menyelenggarakan jaringan pelayanan yang dapat memelihara dan meningkatkan kesejahteraan warga negara secara adil dan berkelanjutan. Artinya, bahwa negara kesejahteraan adalah adanya suatu negara, bahwa pemerintahan negara dianggap bertanggung jawab untuk menjamin standar kesejahteraan hidup minimum bagi setiap warga negaranya (Ni'matul Huda: 2006). Konsep negara kesejahteraan sangat erat kaitannya dengan kebijakan sosial (social policy) yang di banyak negara mencakup strategi dan upaya-upaya pemerintah dalam meningkatkan kesejahteraan warganya, terutama melalui perlindungan sosial (social protection) yang mencakup jaminan sosial baik berbentuk bantuan sosial dan asuransi sosial, maupun jaring pengaman sosial (social safety nets).Sekurang-kurangnya ada lima bidang utama yang disebut Spicker untuk menjelaskan konsep kesejahteraan, yaitu: bidang kesehatan, bidang pendidikan, bidang perumahan, bidang jaminan sosial, dan bidang pekerjaan sosial.

Istilah kesejahteraan atau sejahtera dapat memiliki empat arti, yakni: (1) Dalam istilah umum, sejahtera menunjuk ke keadaan kondisi manusia yang baik, dimana orang-orangnya dalam keadaan makmur, dalam keadaan sehat, dan damai; (2) Dalam tinjauan ekonomi, sejahtera selalu dihubungkan dengan keuntungan atau manfaat kebendaan (ukuran materi) sebagai fungsi kesejahteraan sosial (secara formatif dan substantif bisa bermakna ekonomi kesejahteraan atau kesejahteraan ekonomi); (3) Dalam tinjauan kebijakan sosial, kesejahteraan sosial menunjuk ke jangkauan pelayanan untuk memenuhi kebutuhan masyarakat. Ini adalah istilah yang digunakan dalam ide negara kesejahteraan (welfare state); (4) Dalam tinjauan lain (seperti fenomena kebijakan di negara maju seperti Amerika), sejahtera menunjuk ke aspek keuangan yang dibayarkan oleh pemerintah kepada orang yang membutuhkan bantuan finansial, tetapi tidak dapat bekerja; atau yang keadaan pendapatan yang diterimanya untuk memenuhi kebutuhan dasar tidak cukup atau tidak layak secara manusiawi; atau jumlah yang dibayarkan biasanya jauh di bawah garis kemiskinan; atau bisa 
Darmini Roza dan Gokma Toni P.S: Partisipasi Masyarakat Dalam Pembentukan...

juga karena memiliki kondisi khusus, seperti adanya bukti sedang mencari pekerjaan (menganggur); atau kondisi lain, seperti ketidakmampuan atau kewajiban untuk menafkahi keluarga atau menjaga anak (yang mencegahnya untuk dapat/bisa bekerja), karena di beberapa kasus negara penerima dana diharuskan bekerja, yang dikenal dengan istilah workfare. Hal ini, tampaknya berbeda dengan yang terjadi di Indonesia, kasus Bantuan Langsung Tunai (BLT), Bantuan Langsung Sementara Tunai (BLST) atau bentuk-bentuk bantuan lain yang lebih bersifat kedermawanan (charity), yakni tidak ada kewajiban atau keharusan bagi penerima untuk bekerja (Aristo Evandy Barlian: 2016).

Konsep negara kesejahteraan tidak hanya mencakup deskripsi mengenai sebuah cara pengorganisasian kesejahteraan (welfare) atau pelayanan sosial (social services), melainkan juga sebagai sebuah konsep normatif atau sistem pendekatan ideal yang menekankan bahwa setiap orang harus memperoleh pelayanan sosial sebagai haknya. Oleh karena itu, konsep negara kesejahteraan ada juga yang menyebut sebagai anak kandung pergumulan ideologi dari teori sosialisme (Laurensius Arliman S: 2016). Anehnya, di dalam praktik kenegaraan konsep negara kesejahteraan ini justru banyak dilakukan dan berkembang di negara-negara demokratis dan kapitalis (Almanar, Husni A. Jalil, Nur Rasyid: 2017), bukan di negara- negara sosialis; yakni konsep Negara kesejahteraan sering dipandang sebagai sebuah strategi "penawar racun" konsep kapitalisme, yakni mengurangi dampak negatif dari sistem ekonomi pasar bebas, dengan menggunakan prinsip negara yang miskin (sakit) tidak mungkin membantu atau menyejahterakan rakyat atau warga negara yang miskin (sakit); Oleh karena itu, ada pula yang mengatakan bahwa sesungguhnya konsep welfare state itu tidak lain merupakan bentuk strategi dari kapitalisme yang baik hati (compassionate capitalism).

\section{Partisipasi Masyarakat Dalam Pembentukan Perundang- Undangan}

Jika dicermati bahwa hukum merupakan himpunan peraturan-peraturan yang dibuat oleh pihak yang berwenang dan perundang-undangan merupakan proses dan teknik penyusunan dari himpunan peraturan hukum, maka dapat ditarik sebuah garis bahwa suatu hukum harus diproduksi sebagai produk hukum dengan sebuah proses dan teknik yang kemudian disebut sebagai peraturan perundang-undangan. Peraturan perundang-undangan harus mempunyai kriteria bersifat tertulis, mengikat umum, dan dikeluarkan oleh Pejabat atau Lembaga yang berwenang (Firman Freaddy Busroh: 2016). Dalam sistem demokrasi partisipasi masyarakat pada hakekatnya adalah sarana untuk: 1) menghindari penyalahgunaan kekuasaan oleh pemimpin; 2) menyalurkan aspirasi masyarakat (warga) kepada pemerintah; 3) melibatkan warga dalam pengambilan keputusan publik; 4) menegakkan 
kedaulatan rakyat. Partisipasi adalah hak sekaligus kewajiban warga untuk menegakkan tata pemerintahan yang baik.

Parameter peraturan perundangundangan yang partispatif bisa dilihat dari (Moh. Fadli, Jazim Hamidi dan Mustafa Lutfi: 2017): 1) penyusunan peraturan perundang-undangan dijalankan dengan tujuan untuk menyelenggarakan tata pemerintahan yang baik; 2) partisipasi, akuntabilitas, keterbukaan dan pengawasan agar tidak terjadi penyalahgunaan terhadap anggaran pembangunan pemerintahan, merupakan dasar-dasar yang prinsipal dalam penyusunan peraturan perundangundangan; 3) partisipasi dalam penyusunan peraturan pemerintahan merupakan hak sekaligus kewajiban masyarakat; 4) adanya pemberdayaan para pihak agar mampu berpartisipasi secara seimbang; 5) setiap aspirasi diperhatikan tanpa terkecuali; 6) pengambilan keputusan melalui proses yang jujur, terbuka dan adil; 7) adanya akses yang luas terhadap berbagai informasi yang merupakan hak publik; 8) adanya mekanisme penilaian terhadap hasil-hasil keputusan dan pelaksananya.

Sirajuddin mengklasifikasikan kedelapan tingkat partisipasi tersebut di atas menjadi tiga tingkat antara lain: 1) tingkat pertama diklasifikasikan sebagai tidak partisipasi (non participation) yaitu tingkat manipulasi dan terapi, 2) tingkat kedua disebut dengan partisipasi semu (degree of takenism), yaitu tingkat peredaman, konsultasi, dan informasi. Dalam tingkatan kedua ini masyarakat didengarkan dan diperkenankan berpendapat, tetapi tidak memiliki kemampuan dan tidak ada jaminan bahwa pandangan mereka akan dipertimbangkan secara sungguh-sungguh oleh penentu kebijakan, 3) tingkat ketiga adalah kekuasaan masyarakat (degree of citizen power), yaitu tingkat kemitraan, delegasi kekuasaan dan kendali masyarakat. Dalam tingkat ini masyarakat memiliki pengaruh dalam proses penentuan kebijakan.

Tingkat tertinggi atau pertama adalah kontrol warga negara (citizen control). Pada tahap ini partisipasi sudah mencapai tataran dimana publik berwenang memutuskan, melaksanakan dan mengawasi pengelolaan sumber daya. Turun ke tingkat kedua delegasi kewenangan (delegated power) di sini kewenangan masyarakat lebih besar daripada penyelenggaraan negara dalam merumuskan kebijakan. Ketiga kemitraan (partnership) ada keseimbangan kekuatan relatif antara masyarakat dan pemegang kekuasaan untuk merencanakan dan mengambil keputusan bersama-sama. Tiga tangga ini mengakui eksistensi hak rakyat untuk membuat peraturan perundang-undangan (Sirajuddin: 2006).

Tangga keempat sampai keenam mengindikasikan partisipasi semu. Terdiri dari peredaman (placation) konsultasi dan informasi (informing). Di tangga peredaman rakyat sudah memiliki pengaruh terhadap kebijakan tetapi bila akhirnya terjadi votong pengambilan keputusan akan tampak sejatinya keputusan ada di tangan lembaga negara, 
Darmini Roza dan Gokma Toni P.S: Partisipasi Masyarakat Dalam Pembentukan...

sedangkan kontrol dari rakyat tidak amat sangat menentukan (Laurensius Arliman S: 2016). Di tangga konsultasi rakyat di dengar pendapatnya lalu disimpulkan, rakyat sudah berpartisipasi dalam membuat peraturan perundang-undangan dan lembaga negara sudah memenuhi kewajiban, melibatkan rakyat dalam membuat peraturan perundang-undangan. Sementara di tangga informasi rakyat sekedar diberi tahu akan adanya peraturan perundang-undangan, tidak peduli apakah rakyat sudah memahami pemberitahuan itu, apalagi memberikan pilihan guna melakukan negosiasi atas kebijakan itu. Tangga ketujuh dan kedelapan, terapi dan manipulasi menunjukkan keadaan partisipasi. Di tangga terapi kelompok kebijakan masyarakat korban kebijakan dianjurkan mengadu kepada pihak yang berwenang tetapi tidak jelas pengaduan itu ditindaklanjuti atau tidak. Paling sial di tangga manipulasi lembaga negara melakukan pembinaan terhadap kelompok-kelompok masyarakat untuk seolah-oleh berpartisipasi padahal sejatinya yang terjadi adalah kooptasi dan represi penguasa.

Partisipasi tidak cukup hanya dilakukan segelintir orang yang duduk dalam lembaga perwakilan karena institusi dan orang-orang yang duduk dalam lembaga perwakilan seringkali menggunakan politik atas nama kepentingan rakyat untuk memperjuangkan kepentingan pribadi atau kelompok mereka sendiri. Partisipasi rakyat secara langsung akan membawa tiga dampak penting, yakni: 1) terhindar dari peluang terjadinya manipulasi keterlibatan rakyat dan memperjelas apa yang dikehendaki masyarakat; 2) memberi nilai tambah pada legitimasi rumusan perencanaan; dan 3) meningkatkan kesadaran dan ketramoilan politik masyarakat (Alexander Abe: 2002).

Masalah-masalah yang hidup dalam masyarakat harus dapat diidentifikasi secara jelas oleh aparat pemerintahan agar dapat diteliti dan dicarikan alternatif pemecahan yang tepat untuk dirumuskan sebagai kebijakan publik (public policy). Badan atau pusat penelitian dan pusat penelitian dan pengembangan di Departemen-departemen dimaksudkan untuk melakukan penelitian kebijakan yang masuk ruang lingkup departemen yang bersangkutan serta melakukan koordnasi dan konsultasi dengan instansi pemerintahan yang terkait dan dapat pula memanfaatkan dan diputuskan untuk kemudian dilaksanakan dan selanjutnya dievaluasi apakah kebijaksanaan tersebut benar-benar telah mengenai sasaran yang diharapkan (M. Solly Lubis: 2009). Sehingga partisipasi masyarakat untuk menciptakan peraturan yang responsif kepada masyarakat semakin terlihat dan ada pembandingnya dengan penelitian yang dilakukan oleh pihak yang telah disebutkan.

Bila kita beranjak pada Pasal 96 UUP3 menyatakan bahwa: ayat (1) Masyarakat berhak memberikan masukan secara lisan dan/atau tertulis dalam Pembentukan Peraturan Perundangundangan. Ayat (2) Masukan secara lisan 
dan/atau tertulis sebagaimana dimaksud pada ayat (1) dapat dilakukan melalui: a) rapat dengar pendapat umum; b) kunjungan kerja; c) sosialisasi; dan/atau d) seminar, lokakarya, dan/atau diskusi. Ayat (3) masyarakat sebagaimana dimaksud pada ayat (1) adalah orang perseorangan atau kelompok orang yang mempunyai kepentingan atas substansi Rancangan Peraturan Perundangundangan. Ayat (4) Untuk memudahkan masyarakat dalam memberikan masukan secara lisan dan/atau tertulis sebagaimana dimaksud pada ayat (1), setiap Rancangan Peraturan Perundang-undangan harus dapat diakses dengan mudah oleh masyarakat.

Dari ketentuan tersebut sebenarnya sudah menjelaskan bagaimana partisipasi masyarakat dalam pembentukan perundang-undangan yang baik dan bersifat responsif di Indonesia. Namun pembentukannya terkadang di dalam implementasi belum seperti yang ada di dalam konsep-konsep teoritis dan normatif seperti yang dijelaskan di atas, pembentukan perundang-undangan lebih condong kepada kepentingan politik yang berwenang membentuk peraturan perundangan-undangan dalam ranah legislatif.

\section{Mewujudkan Pembentukan Undang-Undang Menuju Negara Indonesia yang Sejahtera}

Paham negara kesejahteraan sejatinya dapat diterapkan berdampingan dengan negara regulasi. Kesejahteraan adalah impian berbangsa dan menjalankan fungsi pengaturan adalah sarana pencapaiannya.
Penyelarasan dua konsep ini bukanlah sesuatu yang tidak mungkin. Tentu dengan pembentukan peraturan perundang-undangan yang responsif dan mengedepankan kepentingan rakyat, maka konsep negara kesejahteraan Indonesia ini akan terwujud.

Pasal 5 UUP3 menyatakan bahwa dalam membentuk Peraturan Perundangundangan harus dilakukan berdasarkan pada asas Pembentukan Peraturan Perundang-undangan yang baik, yang meliputi: a) kejelasan tujuan; b) kelembagaan atau pejabat pembentuk yang tepat; c) kesesuaian antara jenis, hierarki, dan materi muatan; d) dapat dilaksanakan; e) kedayagunaan dan kehasilgunaan; f) kejelasan rumusan; dan e) keterbukaan. Sedangkan di Pasal 6 ayat (1) UUP3 menyatakan bahwa materi muatan Peraturan Perundang-undangan harus mencerminkan asas: a) pengayoman; b) kemanusiaan; c) kebangsaan; d) kekeluargaan; e) kenusantaraan; f) bhinneka tunggal ika; g) keadilan; h) kesamaan kedudukan dalam hukum dan pemerintahan; i) ketertiban dan kepastian hukum; dan/atau j) keseimbangan, keserasian, dan keselarasan. Ayat (2) selain mencerminkan asas sebagaimana dimaksud pada ayat (1), Peraturan Perundang-undangan tertentu dapat berisi asas lain sesuai dengan bidang hukum Peraturan Perundang-undangan yang bersangkutan. Pembentukan dan materi muatan peraturan dalam UUP3 sebenarnya sudah mencerminkan bagaimana konsep pengaturan negara 
Darmini Roza dan Gokma Toni P.S: Partisipasi Masyarakat Dalam Pembentukan...

kesejahteraan Indonesia, namun dalam implementasinya masih "jauh panggang dari api".

Jika kita bandingkan pembentukan dan materi muatan peraturan dalam UUP3 dengan pendapat I.C Van der Vlies dalam mewujudkan pembentukan peraturan perundang-undangan menuju negara kesejahteraan Indonesia maka asas-asas yang baik (beginselen van behoorlijk regelgeving) ke dalam asas-asas yang formal meliputi (Laurensius Arliman S: 2015): a) asas tujuan yang jelas; b) asas organ/lembaga yang tepat; c) asas perlunya pengaturan; d) asas dapatnya dilaksanakan dan e) asas konsensus, dan materialnya meliputi: a) asas tentang terminologi dan sistematika yang benar; b) asas tentang dapat dikenali; c) asas perlakuan yang sama dalam hukum; d) asas kepastian hukum; e) asas pelaksanaan hukum sesuai keadaan individual (Maria Farida Indrati S: 2007).

Sedangkan A. Hamid S. Attamimi berpendapat bagi pembentukan peraturan perundang-undangan Indonesia, terutama menyangkut dalam mewujudkan pembentukan peraturan perundangundangan menuju negara kesejahteraan Indonesia yang patut asas-asas tersebut secara berurutan dapat disusun sebagai berikut: a) cita hukum Indonesia; b) asas negara berdasar hukum dan asas pemerintahan berdasar sistem konstitusi; c) asas-asas lainnya. Dengan demikian, asas-asas pembentukan peraturan perundang-undangan Indonesia yang patut akan mengikuti pedoman dan bimibingan yang diberikan oleh: a) cita hukum Indonesia yang tidak lain Pancasila, sila-sila dalam hal tersebut berlaku sebagai cita (idee) yang berlaku sebagai bintang pemandu; b) norma fundamental negara yang juga tidak lain Pancasila (sila-sila dalam hal tersebut berlaku sebagai norma); c) Asas-asas negara berdasar atas hukum yang menempatkan undang-undang sebagai alat pengaturan yang khas berada dalam keutamaan hukum (der Primat ds Rechts) dan asas-asas pemerintahan berdasar sistem konstitusi yang menempatkan undang-undang sebagai dasar dan batas penyelenggaraan kegiatan-kegiatan pemerintahan. Asas-asa pembentukan peraturan perundang-undangan yang patut itu meliputi juga: a) asas tujuan yang jelas; b) asas perlunya pengaturan; b) asas organ/lembaga dan materi muatan yang tepat; c) asas dapat dilaksanakan; d) asas dapatnya dikenali; e) asas perlakuan yang sama dalam hukum; f) asas kepastian hukum; g) asas pelaksanaan hukum sesuai keadaan individual (Maria Farida Indrati S: 1998).

Apabila mengikuti pembagian mengenai adanya asas yang formal dan asas yang material, maka A. Hamid S. Attamimi cenderung untuk membagi asasasas pembentukan peraturan perundangundangan yang patut tersebut ke dalam (Gokma Toni: 2018): a) pertama, yaitu asas-asas formal, dengan princian: 1) asas tujuan yang jelas; 2) asas perlunya pengaturan; 3) asas/organ lembaga yang tepat; 4) asas materi mautan yang tepat; 5) asas dapat dilaksanakan; dan 6) asas dapatnya dikenali, b) kedua, yaitu asas- 
asas material, dengan perincian: 1) asas sesuai dengan cita hukum Indonesia dan norma fundamental Negara; 2) asas sesuai dengan hukum dasar negara; 3) asas sesuai dengan prinsip-prinsip negara berdasar atas hukum; 4) asas sesuai dengan prinsip-prinsip pemerintahan berdasar sistem konstitusi (Maria Farida Indrati S: 1998).

Dalam hal peran serta masyarakat, Maria Farida Indrati Soeprapto beranggapan bahwa masih terdapat berbagai penafsiran tetang siapa yang dimaksudkan dengan istilah masyarakat, ada yang mengartikan setiap orang pada umumnya, setiap orang atau lembaga yang terkait, atau setiap lembaga swadaya masyarakat yang terkait. Kemudian menjadi pertanyaan dan permasalahan, sampai sejauh mana masyarakat tersebut dapat ikut serta dalam pembentukan peraturan perundang-undangan. Untuk hal tersebut dapat tergantung pada keadaan dari pembentuk peraturan perundangundangan sendiri, oleh karena UUD 1945 dan berbagai peraturan perundangundangan telah menetapkan lembaga mana yang dapat membentuk peraturan perundang-undangan tersebut. Oleh karena, itu diperlukan peningkatan kualitas para anggota Dewan Perwakilan Rakyat dan Dewan Perwakilan Daerah, maupun seluruh jajaran pemerintahan

Dengan mengacu pada asas-asas pembentukan peraturan perundangundangan Indonesia yang patut tersebut dan bentuk asas-asas dalam pembentukan peraturan perundang-undangan di Indonesia, dapat kita harapkan terciptanya peraturan perundang-undangan yang baik dan dapat mencapai tujuan secara optimal dalam pembangunan hukum di Negara Republik Indonesia, terutama mewujudkan pembentukan peraturan perundang-undangan menuju negara kesejahteraan Indonesia dalam hal peran serta masyarakat.

\section{SIMPULAN}

Negara kesejahteraan adalah impian berbangsa dan menjalankan fungsi pengaturan adalah sarana pencapaiannya. Penyelarasan dua konsep ini bukanlah sesuatu yang tidak mungkin. Pembentukan peraturan perundangundangan yang responsif harus mengedepankan kepentingan rakyat, sehingga konsep negara kesejahteraan Indonesia ini akan terwujud. Tantangan yang terjadi pada hari ini adalah suara atau partisipasi masyarakat tidak terlalu didengar dan diterima, atau bahkan hanya formalitas semata dalam pembentukan perundang-undangan di Indonesia. Untuk mewujudkan pembentukan peraturan perundang-undangan yang responsif terutama menyangkut dalam mewujudukan pembentukan peraturan perundang-undangan menuju negara kesejahteraan Indonesia, maka pembentukan peraturan perudangundangan di Indonesia harus tunduk pada Pasal 5 dan Pasal 6 UUP3 terkait pembentukan Perundang-undangan dan taat kepada asas-asas Pembentukan Peraturan Perundang-undangan yang baik. Penulis mengharapkan lembaga legislatif memang benar-benar menjalankan perintah undang-undang dan 
Darmini Roza dan Gokma Toni P.S: Partisipasi Masyarakat Dalam Pembentukan...

memprioritaskan kepentingan rakyat diatas kepentingannya.

\section{DAFTAR PUSTAKA}

Agus Suryono, "Kebijakan Publik Untuk Kesejahteraan Rakyat”, Jurnal Transparansi, Volume 6, Nomor 2, 2014.

Alexander Abe, Perencanaan Daerah Partsipatif, Yogyakarta: Pembaruan, 2005.

Almanar, Husni A. Jalil, Nur Rasyid, Kedudukan Peraturan Pemerintah Pengganti Undang-Undang Dalam Sistem Peraturan PerundangUndangan Di Indonesia, Jurnal Ilmu Hukum, Vol. 3, No. 2, 2017.

Aristo Evandy Barlian, Konsistensi Pembentukan Peraturan Daerah berdasarkan Hierarki Peraturan Perundang-undangan dalam Perspektif Politik Hukum, Fiat Justisia. Vol. 10 No. 4. 2016.

Bisariyadi, "Pergulatan Paham Negara Kesejahteraan (Welfare State) dan Negara Regulasi (Regulatory State) dalam Perkara Konstitusional”, Jurnal Ius Quia Iustum, Volume 23, Nomor 4, 2016.

Eddy Kiswanto, Negara Kesejahteraan (Welfare State): Mengembalikan Peran Negara Dalam Pembangunan Kesejahteraan Sosial Di Indonesia, Jurnal Kebijakan dan Administrasi Publik, Volume 9, Nomor 2, 2005.

Firman Freaddy Busroh, Teknik Perundang-Undangan, Jakarta. Cintya Press, 2016.

Gokma Toni Parlindungan S, Partisipasi Masyarakat sebagai Amanat Konstitusi dalam Rangka
Meningkatkan Masyarakat Patuh Hukum dalam Perspektif Undangundang Nomor 22 Tahun 2009, Ensiklopedia of Journal, Volume 1, Nomor 1, 2018.

Laurensius Arliman S. Peranan Metodologi Penelitian Hukum di Dalam Perkembangan Ilmu Hukum di Indonesia. Jurnal Soumatera Law Review, Volume 1, Nomor 1. 2018.

Laurensius Arliman S. Ilmu Perundangundangan yang Baik Untuk Bangsa Indonesia. Deepublish. Yogyakarta. 2016.

Laurensius Arliman S. Lembaga-lembaga Negara di Dalam Undang-Undang Dasar Negara Republik Indonesia Tahun 1945. Deepublish. Yogyakarta. 2016.

Laurensius Arliman S. Lembaga-lembaga Negara Independen di Dalam Undang-Undang Dasar Negara Republik Indonesia Tahun 1945. Deepublish. Yogyakarta. 2016.

Laurensius Arliman S. Kedudukan Ketetapan MPR dalam Hierarki Peraturan Perundang-Undangan di Indonesia. Lex Jurnalica, Volume 13. Nomor 3. 2016.

Laurensius Arliman S. Partisipasi Aktif Dan Pasif Publik Dalam Pembentuan Peraturan Daerah Di Kota Payakumbuh. Jurnal Lex Librum. Volume 2. Nomor 1. 2015.

Liddle, R. William, Indonesia's Democratic Opening, Journal Government and Opposition. Vol. 34 No.1, 1999.

Maria Farida Indrati S, Ilmu PerundangUndangan, Jenis, Fungsi dan 
Materi Mautan, Yogyakarta. Kanisius, 2007.

Maria Farida Indrati S, Ilmu PerundangUndangan, Dasar-Dasar Dan Pembentukannya, Yogyakarta. Kanisius, 1998

Moh. Fadli, Jazim Hamidi dan Mustafa Lutfi, Pembentukan Peraturan Desa Partsipatif (Head To A Good Village Governance), Malang. UB Press, 2011.

M. Solly Lubis, Ilmu Pengetahuan Perundang-Undangan, Bandung: Mandar Maju, 2009.

Ni'matul Huda, Kedudukan Peraturan Daerah dalam Hierarki Peraturan Perundang-Undangan, Jurnal Hukum, Vol. 13 No. 1. 2006.

Pierre Andre Cote, The Interpertation of Legislation in Canada, $2^{\text {nd }}$ Edition, Quebeec: Les Editions Yvon Balais Inc, 1991.

Rahayu Prasetyaningsih, Menakar Kekuasaan Presiden dalam Pembentukan Peraturan Perundangundangan Menurut Undang-Undang Dasar 1945, Padjadjaran Jurnal Ilmu Hukum. Vol. 4 No. 2. 2017.

Reinstein, Rovert J, The Limits of Executive Power, American University Law Review. Vol. 59, No. 2. 2009.

Retno Saraswati, Perkembangan Pengaturan Sumber Hukum dan Tata Urutan Peraturan Perundang- undangan di Indonesia. Jurnal Media Hukum. Vol. IX, No. 2009.

Rosyid Al Atok, konsep Pembentukan Peraturan Perundnag-Undangan, Teori Sejarah dan Perbandingan Dengan Beberapa Negara Bikameral, Malang: Setara Press, 2015.

Saiful, Eksistensi Peraturan Desa Pasca Berlakunya Undang-Undang Nomor 12 Tahun 2011, Jurnal Ilmu Hukum Legal Opinion, Edisi 6, Vol. 2, 2014.

Sirajuddin, Fatkhurohman dan Zulkarnain, Legislative Drafting: Pelembagaan Metode Partisipatif, Malang: In-Trans Publishing, 2006.

Stewart Fenwick, Administrative Law and Judicial Review in Indonesia: The Search for Accountability, dalam Tom Ginsburg dan Albert HY Chen (eds), Administrative Law and Governance in Asia: Comparative Perspective, New York: Routledge, 2009.

Zaka Firma Aditya, Muhammad Reza Winata, Rekonstruksi Hierarki Peraturan Perundang-Undangan Di Indonesia (Reconstruction Of The Hierarchy Of Legislation In Indonesia), Jurnal negara Hukum, Vol. 9, No. 1, 2018. 